\title{
Anthropology as an Imperial Study*
}

$\mathrm{T}$ HE process of incorporation of subject peoples into a great imperial organization, such as the British Empire, with duties, responsibilities and privileges, for which their previous experience has all inadequately prepared them, only too often has been so severe an ordeal that the novice has succumbed to the hardships involved, and instead of attaining a fuller life in a new society of peoples, has disappeared from among the nations of the earth.

Sometimes this disappearance has been the result of deliberate and calculated severity, as the Easter Islander at the hands of Peru, or the Tasmanians at those of the British. Far more often the fatalities of this ordeal have been the result of ignorance, of indifference or even of kindness misdirected with the best of intentions, as has happened in the Andaman Islands, where the Rev. Mr. Corbyn's policy of attempting to civilize the Andamanese has combined with other factors, such as the introduction of diseases from which the Islanders had not acquired immunity, to reduce the number of inhabitants from 5,000 in 1858 to 460 in 1931 .

The causes of such decline have been variously estimated. A some-time lieutenant-governor of Papua is quoted as writing of "tribes who apparently must disappear before long, and when one considers their habits the only cause of surprise is that they should have come into existence at all". 'The habits specified seem to be child-marriage and "the probability of unnatural offences and other filthy customs", which do not afford convincing testimony of the causes of decline. Native customs, often repugnant to Europeans, such as head-hunting expeditions, are frequently the culminating point of a preparation lasting over years, which has provided interesting work in the building of canoes, etc., punctuated by rites and feasts relieving the monotony of life, and stimulating agriculture and pig-breeding. On the economic side again, the introduction of coin into the Naga Hills of Assam and its greatly increased circulation have led not only to much indebtedness, but also to the growth of a landless class. Loans formerly repaid in kind are now paid in cash, to obtain which something must be sold, generally the land, leading to a loss of independence. Great harm has been done by the complete failure to understand native systems of ownership and tenure of land.

In many parts of Asia and Africa, ownership has been communal. Under this system, destitution is impossible; for the tribe is responsible for all its members. It has happened repeatedly, however, that the chief has been treated as owner and not as trustee, as he really is. The deplorable results can be seen in the landless condition of a large proportion of the Indians of North America, or in conditions among the aboriginal tribes of India, especially in Chota, Nagpur and the Chittagong Hills, where the chief has been converted to Hinduism, and has alienated the land, which belonged to the village,

* Substance of the inaugural lecture of Dr. J. H. Hutton, William Wyse professor of social anthropology in the University of Cambridge, delivered on February 14. and not to him as an individual. A similar misunderstanding of the tribal point of view is likely to arise in the case of many customs, and also in the administration of justice. Among the aboriginals of India the application of a system of law, which they do not understand, has more often than not resulted in ruining them economically and degrading them morally. Even the efforts of missionaries have succeeded in adding to the black man's burden by undermining the prestige of the natural leaders of the people, the pastor encroaching on the prerogative of the chief. When the chief, the medicine man, and other natural leaders become mere figure-heads, native culture no longer offers any objective worthy of effort or sacrifice, and the native lapses into an existence devoid of purpose or ambition, and, therefore, of contentment. A people who have thus lost interest in life succumb to any disease of body or mind and fail to reproduce their species in sufficient quantity to survive the chances of death.

Other causes might be cited, indicating the responsibility for decline-at any rate in part; but if we assume that deoline had set in before the white man came, of what value is the culture he has to offer, if it cannot arrest, but only accentuates, the existing process of decay. We have no right to incorporate in our system peoples of other culture than ours if the ordeal of that incorporation be so severe as to destroy the peoples incorporated.

It is here that the study of anthropology comes in. The first necessity in dealing with a race of so-called 'primitive' culture, as Dr. A. C. Haddon pointed out so long ago as 1921 , is an ability to adopt an attitude in which the observer divests himself entirely of his own outlook on life, and regards everything from the point of view of members of the other race, as they exist for themselves in their own scheme of life. If such a point of view is at all attainable, it is through a study of social anthropology that it can be obtained with least difficulty. For to the anthropologist all customs are natural, and even head-hunting and cannibalism are not revolting crimes, but reasonable and inevitable acts resulting from beliefs and ideas logically applied to circumstances and environment. A failure on the part of administrators and administered to recognize each other's point of view may well lead to rebellion or disturbance, but must certainly lead to apathy, depression and degeneracy on the part of the administered, whereupon, as W. H. R. Rivers pointed out, they languish and die.

The anthropologist can do a great deal towards solving these difficulties, if the various branches of that science act in collaboration. The dangers of apathy, depression, and decline is primarily the province of the social psychologist. If the result of the impact of Western civilization can be foreseen, any sudden upsetting change can be guarded against. Thus an outlet has been provided to take the place of head-hunting in New Guinea, where the substitution of a wild boar has averted the deleterious effects on the marriage rate, which threatened when head-hunting was abolished. Similarly, problems of 
interbreeding and the influence of changed conditions of life, owing to the introduction of new styles of dress or in buildings, call for investigation. For the anthropological economist, problems are raised by changes in the methods of production, and by such measures as the wholesale suppression of slavery, which latter on the Assam-Burmese frontier has thrown land out of cultivation. The introduction of mill-spun yarn or machine woven cloth may completely supersede indigenous manufacture, to the great detriment of certain sections of the community. Again, in Assam, the anthropologist will discover that the administration of previously independent tribes has had a deleterious effect. The old conditions of intermittent warfare, raids, and head-hunting involved competition and a hard life, the need for vigilance, resource and quick reactions. Personal efficiency was the primary standard, and wealth secondary. With the prevention of warfare and raiding, wealth comes to stand first and the whole tribe suffers by the change.

The imposition of taxation is another important factor in change, necessitating the use of money, reading to detribalization and the acceptance of European values. Another difficulty is the belief in witcheraft, which cannot be ignored as a vain superstition, when the people themselves believe in it.

The obstacle in the way of anthropology's contribution to the solution of these and other problems has been in the past largely due to the absence of recognition of the practical value of this science. The end of the Great War, as Rivers prophesied, has brought the duty of meeting old responsibilities in new ways. The feeling is growing in Great Britain that dependencies inhabited by people of primitive culture are held in trust primarily for their in. habitants, and secondarily for the world in general. Those responsible for the administration of such areas have been slow to recognize the value of anthropology in meeting such responsibilities. The Colonial Office, it is true, has now recognized the value of a knowledge of anthropology, and probationers going out do not now go out without at least some knowledge of that science ; but politicians and men of affairs are apt to regard learning and theoretical knowledge with consistent distrust.

\section{Forest Products Research}

\section{$\mathrm{T}$} HE report of the Forest Products Research Board for the year 1936 with the report of the Director of Forest Products Research for the same year (H.M. Stationery Office, Dec. 1937) give evidence of the increasing interest being taken in timber research by industry.

The Board states that the period covered by the report has been of special importance to the Board as it includes a survey of the work and policy of the Forest Products Research Laboratory carried out on behalf of the Department of Scientific and Industrial Research by a Committee appointed for the purpose. It is of public interest to know that inspections of this nature are held periodically by the Department on the various activities under its control and the Board welcomed the opportunity thereby afforded to review the present position and to adjust future policy. Throughout the year, the Board was in close touch with the Reviewing Committee set up by the Department and the suggestions of the Committee were submitted to the Board for opinion at a meeting held at the Forest Products Laboratory at Princes Risborough in October. The Board's comments were afterwards laid before the Advisory Council for Scientific and Industrial Research.

During the year, more than 2,200 inquiries were dealt with at the Forest Products Research Laboratory-or twice the number dealt with five years ago, a fourth of these being from trade sources, asking for advice and assistance in practical problems connected with the seasoning and bending of wood.

As evidence of the varied nature of the work undertaken at the Laboratory, tests were carried out for British firms in the country on a number of species of foreign timbers, on the strength of a new fireresisting wall board, on timbers for aircraft, for furniture and on a method of packing crushed bamboo and on the adhesion of plywood and glued joints generally. Another fourth of the inquiries, the majority from private individuals, related to the attacks on timber by beetles.

An interesting and perhaps unsuspected outcome, as the result of a large number of mechanical tests on selected hardwoods similar in weight, is the determined factor that tropical timbers are generally inferior in resistance to shock (toughness) to those grown in temperate regions. On the other hand, the tropical timbers are appreciably stronger in resistance to compression parallel to the grain. Both these strength properties are fairly closely related to specific gravity or weight per cubic foot and, there. fore, indirectly to one another; but statistical analysis shows that toughness and strength in compression parallel to the grain are inversely related. Search has been made, among the newer Empire timbers from tropical Africa and Asia recently appearing on the markets, for substitutes for ash and hickory but none of outstanding toughness have yet been discovered to replace these two well-known timbers.

The report deals with the investigation work carried out on shrinkage problems, box testing, insect and fungus researches, plywood products and test work in connexion with Empire timbers. Several species of the latter are mentioned. It would appear that in some of these cases the work of the Research Laboratory is in advance of the Colonies and their Forest Departments from which the timbers originate. It is of little practical utility to the trade to know that a timber is of value for a particular purpose when the commercially accessible amounts available in the forest are to a great extent unknown; whilst working plans safeguarding the correct exploitation of the forests, as understood in India, have yet to be drawn up for the greater part of the areas under the Colonial Forest Services. 